\title{
Children's Literature: Dimensions of Imitation and Child Innocence in Mkatshwa's Leo in the Library
}

\author{
Angela Ngozi Dick ${ }^{1}$, Augustine Emeka Ugwumgbo ${ }^{1}$ \\ ${ }^{1}$ Department of English and Literary Studies, Veritas University, Abuja, Nigeria \\ Correspondence: Angela Ngozi Dick, Department of English and Literary Studies, Veritas University, Abuja, Nigeria.
}

Received: May 18, 2020

Accepted: June 15, 2020

Online Published: June 21, 2020

doi:10.5430/elr.v9n2p32

URL: https://doi.org/10.5430/elr.v9n2p32

\begin{abstract}
The $21^{\text {st }}$ century is marked by increased interest in children's literacy. Part of such academic revolution is more emphasis on child literacy and the increase in the production of Children's books. Consequently, this research, studies the characteristics of Children's Literature using the book Leo in the Library. It also understudies the hermeneutics of colour and spelling, showing how the author used them to express children's innocence. It uses mimetic theory to analyze the book. Thus, it evaluates how the story book Leo in the Library imitates or mirrors the worldview, life and aspirations of children in this century. The research discovered and outlined many characteristics of children's literature as can be perceived from the book Leo in the Library. They include childlike stories, simplicity of expressions, use of illustrations, attractive colours and pictorial representations, inculturation into social values, shaping the creativity of future writers, centres the child into the possibility of the demand of the emerging world, among others. The writer recommends that children's literature texts have to be, colourful, didactic, attractive and full of illustrations. This research identifies the characteristics of children's literature based on Leo in the Library using mimetic theory. It also looks into how child's innocence is depicted by the use of colour and spelling on the cover page of Leo in the Library as shown in the illustration below
\end{abstract}

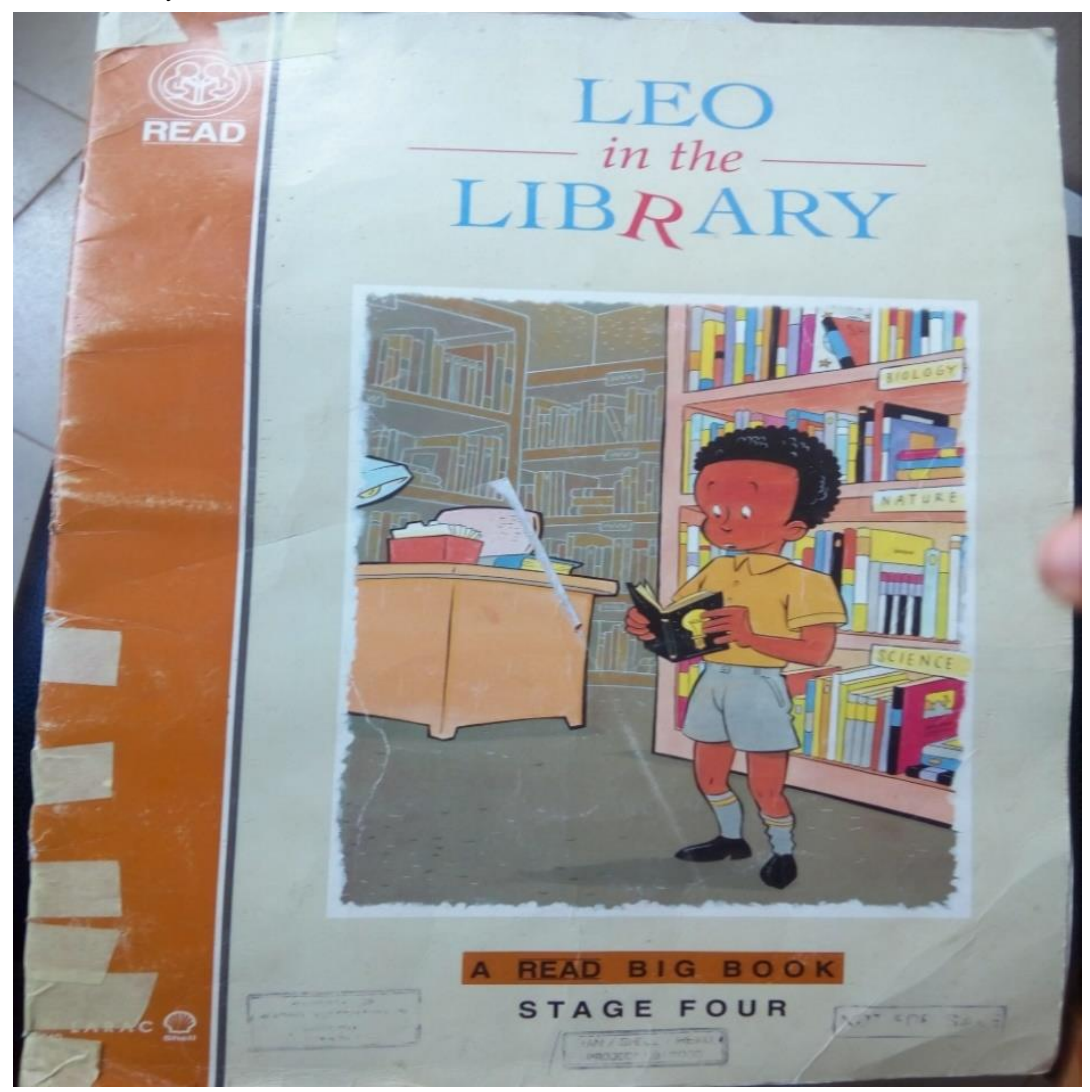


Keywords: children's literature, imitation, child innocence

\section{Introduction: Dimensions of Children's Literature}

According to Machado (1999), children's literature is:

An important beginning step on the child's path to literacy, as well as an excellent source of listening activities for the young child. Seeing, touching and interacting with books is part of a good quality program in early childhood education. Books play an important role in language development (p.210).

The above assertion speaks of positive steps towards child's literacy. And according to Bettelheim and Zelan cited in Machado (1999): "A positive attitude towards literacy is most easily established early in life" (p.210). Consequently, "when handled with care, reading experiences at home and at school can create positive attitudes towards literature and helps to motivate the child to learn to read" (Machado, p.210). This concept of child's literacy forms the crux of the story book Leo in the Library. Reynolds (2009), engages this opinion further in these expressions:"it is often physically small texts that turn out to be capable of filling the minds of generations of young readers with experiences, emotions, and the mental furniture and tools necessary for thinking about themselves and the world they inhabit (p.99). Children's literature is therefore geared towards transformation, navigating between the present world order and nascent worldview.

According to Kadizadi \& Sakar (2019), "children's literature is the literary work concerned with the level of interest, need, readiness and development of children" (p.25). For Sinner, Children's literature is: "The literary disposition constituting works written, compiled and arranged to prepare children for the future based on their age, interest, needs and expectations" (quoted in Kadizadi \& Sakar, (pp.25-26). For further clarity on what constitutes children' literature, Sever, cited by Kadizadi \& Sakar (2019) argues that:

Children's literature (letters) is the general work that enhances children's ability to appreciate and enrich their work of emotions and thoughts with linguistic and visual messages of artistic quality based on their language development and comprehension levels, starting from early childhood to puberty (p.26).

The book Leo in the Library is one of such books. Such literature affects children's social or cultural integration, personality development, linguistic development, and cognitive development. Once again, Reynold's insight is relevant here: "the primary function of children's literature is to secure the child in culture: it is coercively normalizing ... no disturbance at the level of language, no challenge at our [adult's]own sexuality, .... (p.103)."

From the insights above, children's literature is important for the overall development of the child. Beyond the arguments for children's literature as noted introducing the child to early reading opens the door of literacy, builds positive attitudes about books and reading on children, helps them explore the meaning in human experience, access the diversity and complexity of life, feel the texture of the experiences of other people (Machado p. 211).

There are other referents for texts that appeal to children's readership. According to Falconer (2009), "crossover literature has emerged as a way of referring to this category of fiction, aimed at a primary audience of child readers, but also engaging substantial numbers of adult readers (p.366)." Adult readership of children's literature makes it difficult at times to classify into a genre. Drawing on this, one of the foremost scholars of children's texts, Wall (1991,pp.20-36) identifies three speaking voices in children's literature: "single address to a child reader alone; double address to a child and to an adult reading over the child's head; dual address to the child and an adult as equal (qtd. in Falconer 2009, p.369).

\section{Imitation and Literature}

Literary criticism evaluates a text so that the reader will be involved in the fictional world created by the author. It does this by defining, explaining or judging the text. Abrams and Harpham (2012), propose : "an explicit theory of literature, in the sense of general principles, together with a set of terms, distinctions, and categories, to be applied to identifying and analyzing works of literature, as well as the criteria (the standard or norms) by which these works, and their writers are to be evaluated "(p.67). The theoretical framework that defines this research is mimetic theory.

Mimetic theory, otherwise known as the theory of imitation is an imitation or a representation of something 
else rather than an attempt to literally duplicate the original (Abrams \& Harpham 2012, p. 77).The term mimesis is usually translated as 'imitation' or 'representation', though the concept is much more complex than that and does not translate easily into English. Deriving from the postulations of Abrams \& Harpham (2012), there are two senses in which imitation is used in literary criticism. First, it defines the nature of literature and the other arts. For instance, in his Poetics, Aristotle defines poetry as an imitation of human action (Abrams \& Harpham 2012, p. 77). Secondly, it portrays the relationship between two literary works, in which one literary work serves as the model the another. For example, the Greek and Roman rhetoricians and critics often recommended that a poet should "imitate" the established models in a particular literary genre (Abrams \& Harpham 2012, pp.171-172).

The first sense of mimesis is to be used in this research. Thus, the work considers how the author's presentation of children's life in Leo in the Library achieves verisimilitude in the reading child of the $21^{\text {st }}$ Century child.

Two well known scholars, Oha and Uwaegbute (2010) attempted the following illustrations:

A play about World War II is an attempt to take the essence of an actual complex historical event involving millions of people and thousands of square miles over several years and recreate that event in a simplified representation involving a few dozen people in a few thousand square feet over a few hours. The play would be a mimesis of that historical event using stage props, lighting, and individual actors to convey the sense of what World War II was to the audience (p.77).

This research is tasked with showing how the text Leo in the Library imitates the world, life and aspirations of children. Such imitation is also extended specifically to the life of children in the $21^{\text {st }}$ century, in which child education is centred in global narrative., Consequently, the degree to which each form of art like Leo in the Library, accurately embodies the essence of its subject- the world, life and aspirations of children in the $21^{\text {st }}$ century, determines the degree of its success ( Oha \& Uwaegbute, p.77).

\section{Child Innocence: The Size of Objects}

Teaching and studying Children's Literature reminds one of childhood experiences and the emotional strain thereof. The growing child wants to be like grown-ups but power relations between the adults and the growing child frustrates the child. What children do is meaningful to them but the adult has to guide them into "a redemptive future, full of bliss, deserving of pride and honour deriving from the values of their cultural ambience" (Nnabuko 1992, p.190). Anozie (1992) propounds the theory of children's literature book as that which:

Must take its context from the background the child knows, and even where a writer exiles and indulges children by offering them escape, psychological freedom and wonder through fantasy or the supernatural, and even where fantastical characters are made so interesting as to induce suspension of disbelief there must be a logic that would anchor fantasy in reality, enabling the child reader to move easily between fantasy and reality. . . provide useful insights into a child's real life and culture ( p.22).

However, some scholars on child development like Buhler-Niederberger (2015) explain child innocence theologically. According to her, child innocence refers to the child's simplicity, his lack of knowledge and his purity not yet spoiled by mundane affairs (p.1). For this writer child innocence will be represented as naivety, the child's thirst to explore the layers of experience in his environment that initiate him into his culture. For example the size of an object determines the size of the book about that object as portrayed in Mkatshwa's Leo in the Library. This thread of thought sustains both the child and adult readers serving as subtle meanings of portraying child innocence. This platform according to Wilson-Tagoe (1992) is a subtle means of making character dialogue ... sound as if it is taking between actual people (p.21). The dialogue in the library is the platform of the expression of innocence:

Ants are small and black... so books about ants must be small and black. Elephants are fat and grey. Let us look for books that are fat and grey (p.8). Trees are tall and green. We must look for tall green books (Leo in the Library, pp.6-10). 


\section{Style: Colour and Child Innocence in Leo in the Library}

Style differs from one author to the other. It is an author's narrative strategy to make the fictional characters he has created plausible and believable. Colour on the other hand facilitates children's love for learning, and acts as stimulus for learning. For the child learner Mkatshwa's Leo in the Library "Ants are small and black... so books about ants must be small and black. Elephants are fat and grey" (Leo in the Library pp.6-10). Expressions like these evoke Kornei Chukovsky's Theory of Nonsense quoted by Styles (2009) in which Chukovsky suggests that verbal nonsense strengthens the child's sense of reality (Styles p.211):

Kornei Chukovsky notes children's delight in puns and riddles as not just turning word meanings upside down. ... He also stresses the universality of nonsense, identifying the inexhaustible need of every healthy child of every era and of every nation to introduce nonsense into his small but orderly world (p.211).

This appeal to verbal nonsense enamors Leo and his classmates to upturn the bookshelves as the search for books that measure the sizes and colours of elephants and ants by aspiration. In Leo in the Library, sound devices (assonance and alliteration) examples; ants and animal, black and book (p.18), brown book, a big green book (p.19) resonate Kornei Chukovsky's Theory of Nonsense. This gives urgency to the children's resolve to do independent work while Mrs Dube, the school librarian is absent. The sound devices employed in the expressions above make the words new and fantastic for the child reader. Cerrato's assertion on the psychology of colour is telling:

More recently studies have shown that colour can affect you when you do not see them. According to Kurt Goldstein, a blindfolded person experiences physiological reactions under rays of different colors. In other words, the skin reads color, and our bodies, minds, and emotions respond. This happens because the pineal gland is attached to the human brain, which controls the daily rhythms of life. When light enters through the eyes or skin, it travels along neurological pathways to this pineal gland. Different colours give off different wavelength frequencies, and these different frequencies have different effects on us (Cerrato 4 hermancerrato.com/graphic-design).).

According to Cerrato, red colour shows excitement, strength, passion, danger, speed among others. Pesonal encounter with colours show that red is the colour of fire and blood. It is a very emotionally intent color. It is the color of love characterized by high visibility. That is why the stop signs, stoplights and fire equipment are usually painted red. Red orchestrates the themes and images it represents. It is often used as an accent colour to stimulate people to make quick decisions. It is usually found in advertisement dialogue boxes on the internet and websites like: "Buy Now", or Click-here buttons. Thus, if you want to draw attention, use red. It is often where the eye looks first (cf. Cerrato 4). This brings out the strength and passion in a child and channels him positively to literacy. (Cerrato 4 , hermancerrato.com/graphic-design).

From the above point, the hermeneutics of colour is instructive. It nourishes the comprehension of the child reader. On the cover page of Leo in the Library the person conceived as Leo is wearing a yellow shirt. Yellow is the colour of sunshine associated with joy, happiness, and stimulates mental activities. Hence, Mkatshwa used these colours in Leo in the Library as attention catching devices. Besides, localizing the setting of the text in the library will encourage the child reader to read more books and visit the library often.

\section{Spelling Calligraphy}

Besides the use of colour in Leo in the Library, how the author positions the letter $R$ on the title page in a calligraphic inscription distinct from others will engage the reader's imagination to interrogate its stylistic implications. The $\mathrm{R}$ written in slanting position $[R]$ with a contrasting colour serves as a gradient to awaken child innocence and curiosity. The child reader feels he is represented and wants to respond to the text. The style of shifting from colour to calligraphy shows that "visual imagery is an important contributor to reading pleasure, encouraging reader involvement" (Rudd, 2009, p.176). The use of hardcover is part of the tradition of making a book attractive for children while it reduces the preponderance of destroying the book as children struggle over who reads first.

\section{Conclusion}

Teaching and studying Children's Literature is a worthwhile human experience that reminds the teacher of his childhood experiences. Children's Literature also explores in retrospection the emotional strain of growing up. The growing child wants to be like grown-ups but power relations between the adults and the growing child frustrates the child. Through this research the author's style of using a combination of different colours and shapes bequeaths adventure to the child's cognition. Even in using calligraphic design in the title of the book as shown in the photograph of the text above the author of Leo in the Library makes a case for child learning and literacy education 
in colours; and simply an attention catching calligraphic style. The spelling was written in bold letters to emphasize child's cognitive innocence epitomized in the story with the idea of big animals being represented in big books while small animals will be found in small books (Leo in the Library, pp. 8 -19). Some of the characteristics of children's literature were identified. They include among others simplicity, illustration, repetition, colourful pictorials. Considered too were the use of colour and spelling to express children's innocence. Thus, this research recommends that more and better illustrations through the spelling and pictorial representation of concepts should be encouraged in children's literature.

\section{References}

Abrams, M., \& Harpham, G. (2012). A glossary of literary terms. U.S.A: Wadsworth.

Anozie, S. O. (1992). The drum and the flute: Reconstruction in Children's Literature. Children and Literature in Africa. Eds. Ikonne, C.Oko E., Onwudinjo, P.Calabar Studies in African Literature. Ibadan: Heinemann, pp.1-17.

Buhler-Niederberger, D. (2015). Innocence and childhood. Oxford bibliographies.comDoi10.1093/OBO/7780199791231. Accessed $19^{\text {th }}$ April, 2020

Cerrato, H. (2019). The Meaning of Colour. Hermancerrato.com/graphic-design/images/the-meaning-of-colors-book. Accessed $4^{\text {th }}$ December.2019.

Coron, L. (2019). Children's Literature Type. http: //penandthepad.com Retrieved 4/12/2019

Falconer, L. (2019). Cross-reading and crossover books. Children's Literature: Approaches and territories. Ed. Maybin J. \&Watson N. J. (2009). New York: Palgrave Macmillan, pp.366-379.

Kadizadi, D., \& Sakar, C. (2019). Violence and fear in Francesca Simon's series of Horrid Henry. Educational research and reviews, 14, 25-32. https://wwwresearchgate.net

Machado, J. (1999). Early Childhood Experiences in Language Art. New York: Delmar.

Mkatshwa, D. (1996). Leo in the Library. Johannesburg: LARAC, 1996.

Nnabuko, E. O. (2012). Literature and the Nigerian child: The image of the son as a liberated father of the man. Children and Literature in Africa. Eds. Ikonne, C.Oko E., Onwudinjo, P.Calabar Studies in African Literature. Ibadan: Heinemann, pp.187-197.

Oha, A., \& Uwaegbute, C. (2010). All about literature. Lagos: Rose-Hill.

Reynolds, K. (2009). Transformative energies. Children's Literature: Approaches and territories. Ed. Maybin J. \&Watson N.J. (2009). New York: Palgrave Macmillan, pp.91-114.

Rudd, D. (2009). In defence of the defenceless? Some grounds for Enid Blyton's appeal. Children's Literature: Approaches and territories. Ed. Maybin J. \&Watson N. J. (2009). New York: Palgrave Macmillan, pp.168-182.

Styles, M. (2009). From the garden to the street: The history of poetry of children. Children's Literature: Approaches and territories. Ed. Maybin J. \&Watson N. J. (2009). New York: Palgrave Macmillan, pp. 202-217.

Tagoe-Wilson, N. (2012). Children's Literature in Africa: Theoretical and critical issues. Children and Literature in Africa. Eds. Ikonne, C.Oko E., Onwudinjo, P.Calabar Studies in African Literature. Ibadan: Heinemann, pp.18-23. 